- Emphasises the need to undertake CPD in advances in medical practice that may affect prescribing for cardiac conditions which could be risk factors for infective endocarditis.

- Postgraduate organisers should be aware that courses need to be provided to dentists on prescribing antibiotics.

- This paper encourages awareness of which dental devices can be used safely in patients with pacemakers and implantable cardiac defibrillators.

\title{
Cardiac risk factors for dental procedures: knowledge among dental practitioners in Wales
}

\author{
S. A. Thompson, ${ }^{1}$ J. Davies, ${ }_{1}^{2}$ M. Allen, ${ }_{1}^{3}$ M. L. Hunter, ${ }^{4}$ S. J. Oliver, ${ }_{1}^{5}$ S. T. Bryant ${ }^{6}$ and 0. Uzun ${ }^{7}$
}

\begin{abstract}
Objectives To determine knowledge and educational needs of dental practitioners in Wales regarding congenital or acquired cardiac disease and the provision of antibiotic prophylaxis.

Design Self-administered postal questionnaire.

Settings Cardiff University Dental Hospital, district general hospitals (HDS), all general dental practices (GDP) and community dental service (CDS) clinics throughout Wales.
\end{abstract}

Methods A questionnaire sent to 1,182 dentists in Wales in 2004-5. Results 528 questionnaires were returned (a response rate of 45\%). These were analysed using one-way analysis of variance to compare summary scores between the occupation groups. Significant differences in knowledge of cardiac risk factors for infective endocarditis and for dental procedures requiring cover were observed between the occupation groups. The majority of dentists (92\% GDPs, 94\% CDS and $77 \% \mathrm{HDS}$ ) requested postgraduate education in cardiac risk factors and laminated flow diagrams for their surgeries as the preferred educational format.

Conclusion The knowledge of Welsh dentists regarding cardiac conditions or procedures which are risk factors for paediatric and adult patients varied according to place of work. The study identified potential for under- and over-prescription of antibiotic prophylaxis within the current guidance. There was confusion as to which patient

\footnotetext{
${ }^{1 *}$ Clinical Senior Lecturer in Conscious Sedation and Special Care Dentistry, Division of Adult Dental Health, School of Dentistry, Cardiff University, Heath Park, Cardiff, CF14 4XY; ${ }^{2}$ Specialist Registrar in Paediatric Dentistry, Barts and The London, Queen Mary's School of Medicine and Dentistry, Queen Mary, University of London, Turner Street, London, E1 2AD; ${ }^{3}$ General Dental Practitioner/Dental Postgraduate Tutor/Sedation Trainer, ${ }^{4}$ Reader/Honorary Consultant in Paediatric Dentistry, Division of Dental Health and Biological Sciences, ${ }^{5}$ Clinical Lecturer in Restorative Dentistry/Postgraduate Sedation Tutor for Wales, Division of Adult Dental Health, ${ }^{6}$ Research Fellow, Division of Adult Dental Health, School of Dentistry, Cardiff University, Heath Park, Cardiff, CF14 4XY; ${ }^{7}$ Consultant in Paediatric Cardiology, Cardiff and Vale NHS Trust, University Hospital of Wales, Heath Park, Cardiff, CF14 4XW

${ }^{*}$ Correspondence to: Dr Shelagh A. Thompson

Email: thompsonsa@cardiff.ac.uk
}

\section{Online article number E21}

Refereed Paper - accepted 5 March 2007

DOI: 10.1038/bdj.2007.889

${ }^{\circ}$ British Dental Journal 2007; 203: E21 groups and cardiac conditions required prophylaxis and for which particular dental procedures. Postgraduate education detailing advances in cardiology practice is necessary for dentists.

\section{INTRODUCTION}

Surgical and medical advances within the field of cardiothoracic medicine have led to increased survival of patients with both congenital and acquired heart disease. ${ }^{1-3}$ As a result, dental practitioners are increasingly likely to be required to provide treatment for patients with complex cardiac histories $^{4-6}$ whilst medical colleagues may be asked for advice on prophylaxis. ${ }^{7}$ Parents of children with congenital heart disease are becoming more knowledgeable about medical conditions, ${ }^{8}$ although adults with cardiac risk factors may believe their own oral health risks to be less than other people and be unaware of the link between oral and general health. ${ }^{9}$ Hitherto, the main consideration in the dental management of patients with congenital or acquired heart disease has been the provision of appropriate antibiotic prophylaxis when this is clinically indicated.

Certain types of dental procedures and specific cardiac lesions are well recognised as requiring provision of antibiotic prophylaxis for the prevention of infective endocarditis (IE). Unfortunately, in some dental management situations there is controversy as to whether or not this should be provided. ${ }^{10}$ Relevant guidelines have been published by a number of bodies and have been updated periodically. ${ }^{4-6,10,11}$ In 1993, the Endocarditis Working Party of the British Society for Antimicrobial Chemotherapy (BSAC) published guidelines ${ }^{4}$ that were incorporated into the British national formulary and are currently in use in the UK. The BSAC revised its guidance on prevention of endocarditis in $2006^{11}$ but these guidelines have not yet been adopted. The BDA News in September 2006 reported that the Department of Health is considering asking the National Institute of Clinical Effectiveness (NICE) to produce guidance on the issue of antibiotic prophylaxis. The American Heart Association updated their guidelines in $1997^{5-6}$ and the Task Force on Infective Endocarditis of the European Society of Cardiology 


\begin{tabular}{|c|c|c|c|c|c|c|c|c|c|c|c|c|}
\hline \multirow{2}{*}{$\begin{array}{l}\text { Patients } \\
\text { with: }\end{array}$} & \multicolumn{3}{|c|}{ GDP numbers (\%) } & \multicolumn{3}{|c|}{ CDS numbers (\%) } & \multicolumn{3}{|c|}{ HDS numbers (\%) } & \multicolumn{3}{|c|}{ Other numbers (\%) } \\
\hline & Correct & Incorrect & $\begin{array}{l}\text { Don't } \\
\text { know }\end{array}$ & Correct & Incorrect & $\begin{array}{l}\text { Don't } \\
\text { know }\end{array}$ & Correct & Incorrect & $\begin{array}{l}\text { Don't } \\
\text { know }\end{array}$ & Correct & Incorrect & $\begin{array}{l}\text { Don't } \\
\text { know }\end{array}$ \\
\hline $\begin{array}{l}\text { Unrepaired } \\
\text { VSD }\end{array}$ & $303(79)$ & $25(7)$ & $58(15)$ & $80(93)$ & $2(2)$ & $4(5)$ & $33(100)$ & 0 & 0 & $16(69)$ & $5(22)$ & $2(9)$ \\
\hline $\begin{array}{l}\text { Repaired } \\
\text { VSD }\end{array}$ & $119(31)$ & $180(47)$ & $87(23)$ & $33(38)$ & $33(38)$ & $20(23)$ & $17(52)$ & $11(33)$ & $5(15)$ & $11(47)$ & $12(52)$ & 0 \\
\hline $\begin{array}{l}\text { Unrepaired } \\
\text { patent } \\
\text { ductus } \\
\text { arteriosis }\end{array}$ & $243(63)$ & $52(14)$ & $91(24)$ & $71(83)$ & $3(4)$ & $12(14)$ & $27(82)$ & $3(9)$ & 3 (9) & $15(65)$ & $5(21)$ & $3(13)$ \\
\hline $\begin{array}{l}\text { Repaired } \\
\text { patent } \\
\text { ductus } \\
\text { arteriosis }\end{array}$ & $140(36)$ & $133(35)$ & $113(29)$ & $38(44)$ & $23(27)$ & $25(29)$ & $17(52)$ & $9(27)$ & $7(21)$ & $13(56)$ & $8(34)$ & $2(7)$ \\
\hline $\begin{array}{l}\text { Unrepaired } \\
\text { AS defect }\end{array}$ & $281(73)$ & 33 (9) & $72(19)$ & $76(88)$ & $3(4)$ & 7 (8) & $31(94)$ & $1(3)$ & 1 (3) & $15(65)$ & $6(26)$ & $2(9)$ \\
\hline $\begin{array}{l}\text { Repaired } \\
\text { AS defect }\end{array}$ & $118(31)$ & $171(44)$ & $97(25)$ & $31(36)$ & $35(41)$ & $20(23)$ & $16(49)$ & $12(36)$ & $5(15)$ & $10(43)$ & $13(56)$ & 0 \\
\hline $\begin{array}{l}\text { Patent } \\
\text { foramen } \\
\text { ovale }\end{array}$ & $160(42)$ & $73(19)$ & $153(40)$ & $46(54)$ & $11(13)$ & $29(34)$ & $18(55)$ & $9(28)$ & $6(19)$ & $10(43)$ & $6(26)$ & $7(30)$ \\
\hline $\begin{array}{l}\text { Heart valve } \\
\text { replace- } \\
\text { ment }\end{array}$ & 364 (94) & $11(3)$ & $11(3)$ & $82(95)$ & $1(1)$ & $3(4)$ & $33(100)$ & 0 & 0 & $22(96)$ & 0 & 1 (4) \\
\hline $\begin{array}{l}\text { Central } \\
\text { venous } \\
\text { catheter }\end{array}$ & $119(31)$ & $90(23)$ & $177(46)$ & $37(43)$ & $9(10)$ & $40(47)$ & $12(36)$ & $13(39)$ & $8(24)$ & $11(48)$ & $3(13)$ & $9(39)$ \\
\hline $\begin{array}{l}\text { Wolff- } \\
\text { Parkin- } \\
\text { son-White } \\
\text { syndrome }\end{array}$ & $50(13)$ & 29 (8) & 307 (80) & $17(20)$ & $9(10)$ & $60(70)$ & $16(49)$ & $5(15)$ & $12(36)$ & $6(26)$ & $1(4)$ & $16(70)$ \\
\hline $\begin{array}{l}\text { Long QT } \\
\text { syndrome }\end{array}$ & 69 (18) & $6(2)$ & 311 (81) & $26(30)$ & $2(2)$ & $58(67)$ & $16(49)$ & $2(6)$ & $15(46)$ & $8(35)$ & 0 & $15(65)$ \\
\hline
\end{tabular}

published guidelines in 2004, ${ }^{12}$ both differing from the British guidelines. A systematic review conducted by the Cochrane Collaboration $^{13}$ in 2005 stated there was a lack of evidence to support published guidelines and recommended that practitioners should discuss the potential benefit and harm of antibiotic prophylaxis on an individual basis.

In addition to the prevention of IE, a variety of relatively uncommon cardiac conditions may have implications for the dental practitioner. These include long QT (LQT), Brugada and Wolff-Parkinson-White syndromes. There is a need for interaction and effective communication between dentists, ${ }^{14}$ cardiologists and with anaesthetists ${ }^{15}$ when patients are identified with these conditions. Rapidly changing practice in cardiac medicine should be effectively conveyed to dental practitioners so that untoward consequences of dental manipulations on cardiac patients such as the causation of infective endocarditis can be prevented or avoided.

The aim of this study was to examine the knowledge of dentists practising in Wales with regard to cardiac disease, the need for antibiotic prophylaxis (ABC) and the use of electromagnetic dental equipment (such as piezoelectric devices) in patients with pacemakers or implanted defibrillators. Furthermore, the study aimed to establish where dentists normally accessed information regarding need to provide antibiotic cover and finally, to determine the educational needs of dentists in Wales with a view to the development of appropriate educational material.

\section{METHODS}

The Department of Postgraduate Dental Education, Cardiff University holds a database of all general dental practitioners, community dental practitioners and hospital dentists in Wales who are registered with the Department for continuing professional educational needs. This database is the most accurate method of communication with a population of dentists who work within different primary, secondary and tertiary care settings in a geographically diverse country.

From the postgraduate dental education database, a total of 1,182 dentists were identified as practising in Wales. Each dentist was sent a specifically designed questionnaire (Appendix 1) by the Department of Postgraduate Dental Education, together with a covering letter and a stamped addressed envelope for its return. The questionnaire (Appendix 1) included nine questions with multiple sections. There was only one correct answer in each section. Participants were questioned regarding the following topics:

1. Primary place of work (Q1)

2. Knowledge as to which cardiac conditions require antibiotic prophylaxis in paediatric and adult patients (Q2 and Q3) 
3. Knowledge as to which dental procedures require antibiotic prophylaxis in patients at risk of IE (Q4)

4. Knowledge as to which dental equipment should not be used for patients fitted with a pacemaker or implantable cardiac defibrillator (Q5 and Q6)

5. The strategy to be adopted when the requirement for antibiotic prophylaxis was unclear and sources of advice in the management of individual patients (Q7)

6. Continuing postgraduate educational needs were also identified through the questionnaire. Respondents were asked to select (from a range of options) the method by which they would like to receive information regarding the dental management of patients with congenital or acquired cardiac disease (Q8 and Q9).

For questions 2, 3 and 4 (Appendix 1), the percent of questions in each section answered correctly by each respondent was calculated to derive a summary score.

Based on the initial response rate, a second set of questionnaires was sent to dentists within the community dental service (CDS) and hospital dental services (HDS).

The data from the returned questionnaires were analysed using SPSS for Windows Version $12 .{ }^{16}$ One way ANOVA was used to compare groups.

\section{RESULTS}

The initial response rates from the CDS and the HDS were poor and a second mail shot was undertaken. A total of 536 replies were received, however eight questionnaires were incomplete and were discarded from the sample. In total, 528 questionnaires were analysed, an overall response rate of 45\%.

\section{Primary place of work}

Of the 528 dentists, 73\% worked in the general dental service, $16 \%$ in the community dental service and 6\% in district general hospitals or within the teaching hospital in Cardiff. There was some overlap of occupations (4\%) where dentists worked part-time in more than one branch of dentistry. In detail, the 'Other' group consisted of nine specialists in orthodontics and four specialists in other dental specialties (endodontics 2, periodontics 1, oral surgery 1). Seven dentists worked in two areas of care, one in the Armed Forces and one dentist was not working.

\section{Knowledge of which cardiac conditions require antibiotic prophylaxis for paediatric and adult patients}

Each question in turn was discussed by the authors in order to establish a consensus view as to what, based on contemporary UK guidelines, would constitute the correct response for both adults ${ }^{17,18}$ and paediatric patients. ${ }^{17-19}$ These answers are displayed in the questionnaire in Appendix 1. The distribution of responses is displayed in Tables 1-4. One-way analysis of variance was used to compare summary scores for questions 2, 3 and 4 (Table 4) between the occupation groups of dentists.

Conditions that were risk factors for infective endocarditis requiring antibiotic prophylaxis for dental extractions were considered in question 2 (children under 16 years old) and question 3 (adults). The relevant responses are displayed in Tables 1 and 2. The summary scores of mean percentage of correct answers are displayed in Table 4.

The differences observed when examining the responses to the 11 parts of question 2 (children under 16 years old) showed GDPs answered 46\% correctly, CDS dentists 57\%, $65 \%$ for the HDS and 54\% for the 'others' (Table 4). The GDPs had significantly lower knowledge of paediatric cardiac risk factors requiring antibiotic cover than the other groups of dentists $(\mathrm{p}<0.001)$.

The six parts of question 3 related to antibiotic prophylaxis for dental extractions in adult patients (Table 2). GDPs answered on average $62 \%$ of the parts correctly, whilst both CDS and HDS dentists answered 67\% and 'others' answered 68\% (Table 4). There was a statistically significant difference

Table 2 Responses to 03: Which of the following groups of adult patients require antibiotic prophylaxis for dental extractions?

\begin{tabular}{|c|c|c|c|c|c|c|c|c|c|c|c|c|}
\hline \multirow{2}{*}{ Patients with: } & \multicolumn{3}{|c|}{ GDP numbers (\%) } & \multicolumn{3}{|c|}{ CDS numbers (\%) } & \multicolumn{3}{|c|}{ HDS numbers (\%) } & \multicolumn{3}{|c|}{ Other numbers (\%) } \\
\hline & Correct & Incorrect & $\begin{array}{l}\text { Don't } \\
\text { know }\end{array}$ & Correct & Incorrect & $\begin{array}{l}\text { Don't } \\
\text { know }\end{array}$ & Correct & Incorrect & $\begin{array}{l}\text { Don't } \\
\text { know }\end{array}$ & Correct & Incorrect & $\begin{array}{l}\text { Don't } \\
\text { know }\end{array}$ \\
\hline $\begin{array}{l}\text { Innocent heart } \\
\text { murmur (no valve } \\
\text { defects, normal } \\
\text { echocardiogram) }\end{array}$ & $338(88)$ & 36 (9) & $12(3)$ & 85 (99) & - & 1 (1) & $31(94)$ & 1 (3) & 1 (3) & $22(96)$ & $1(4)$ & 0 \\
\hline $\begin{array}{l}\text { Pacemaker or an } \\
\text { implantable cardiac } \\
\text { defibrillator }\end{array}$ & $326(85)$ & $42(11)$ & $18(5)$ & $70(81)$ & $13(15)$ & $3(3)$ & $26(79)$ & $4(12)$ & $3(9)$ & $18(78)$ & $5(22)$ & 0 \\
\hline $\begin{array}{l}\text { Supraventricular } \\
\text { tachycardia and a } \\
\text { structurally normal } \\
\text { heart }\end{array}$ & 356 (92) & $4(1)$ & $26(7)$ & 78 (91) & $2(2)$ & $6(7)$ & 30 (91) & 1 (3) & $2(6)$ & $22(96)$ & $1(4)$ & 0 \\
\hline Vasovagal syncope & $345(89)$ & $3(1)$ & $38(10)$ & $79(92)$ & 1 (1) & $6(7)$ & $29(88)$ & 1 (3) & $3(9)$ & $23(100)$ & 0 & 0 \\
\hline $\begin{array}{l}\text { Hypertrophic } \\
\text { obstructive } \\
\text { cardiomyopathy }\end{array}$ & $56(14)$ & $163(42)$ & $167(43)$ & $26(30)$ & $23(27)$ & $37(43)$ & $12(36)$ & $11(33)$ & $10(30)$ & $8(35)$ & $9(39)$ & $6(26)$ \\
\hline $\begin{array}{l}\text { Wolff-Parkinson- } \\
\text { White (WPW) } \\
\text { syndrome }\end{array}$ & $53(14)$ & $23(6)$ & $310(80)$ & $19(22)$ & $7(8)$ & $60(70)$ & $14(42)$ & $5(15)$ & $14(42)$ & $8(35)$ & $1(4)$ & $14(61)$ \\
\hline
\end{tabular}


between the groups $(p=0.02)$ for knowledge of cardiac risk factors for adult patients.

\section{Knowledge of which dental procedures require antibiotic} prophylaxis in patients at risk from infective endocarditis The eight parts of question 4 (Table 3) showed that GDPs answered a mean of $47 \%$ correctly whilst all the other groups (CDS, HDS and others) had on average 53\% of correct responses (Table 4). There was a highly significant difference in knowledge between the groups ( $p<0.001)$.

Knowledge of which dental equipment should not be used for patients with a pacemaker or an implantable cardiac defibrillator The majority of dentists (78\% GDPs, 80\% CDS and 82\% HDS dentists) would not use an ultrasonic scaler to perform a scale and polish in a patient fitted with a pacemaker or an implantable cardiac defibrillator (ICD). In addition, most dentists (75\% GDPs, 62\% CDS and 73\% HDS dentists) stated that other dental equipment would be contraindicated in such patients. Specifically, in the free comment section, 34\% of dentists would not use electrocautery devices, 6\% would not use an apex locator and 3\% were concerned about the use of an electric pulp tester. Other responses (in brackets) included Diagnodent (3), OPG machines (3), lasers (2), LED light curing machines (2), TENS machines (2), sonic toothbrushes (1), belt driven chairs (1), electric motors (1) and piezoelectric devices (1).

\section{Strategy to be adopted when advice required on} antibiotic prophylaxis

Dentists differed regarding whom they would refer to when unsure if there was a need to provide antibiotic prophylaxis. The majority of dentists working in hospital (85\%), community (59\%) or 'other' (55\%) environments were more likely to refer to a cardiologist directly, whilst those working in general dental practice (46\%) were more likely to contact the patient's general medical practitioner for advice. Surprisingly, only $4 \%$ of GDPs stated they would refer to a dental hospital or local oral surgery unit.

\section{Continuing educational needs and preferred method of learning} Dentists working within the GDS (92\%) and the community dental services (94\%) were more likely than those working in the HDS (77\%) to perceive a need for a formal postgraduate course. The majority of dentists in general dental practice $(74 \%)$ and $65 \%$ of those in the community dental service stated that they would prefer to receive updated guidance on antibiotic prophylaxis in the form of a laminated flow diagram. Only $52 \%$ of hospital-based dentists preferred this format. Interestingly, information in the form of a CD-ROM or an email update was preferred by only a small percentage of respondents.

\section{DISCUSSION}

\section{Primary place of work}

The responses of the dentists were separated into their main place of work. The size of the sample provided suitable numbers for statistical analysis, although a higher response rate would have improved the response bias that can occur in questionnaire-based studies. Whilst there were more replies from GDPs, the percentage of responses (compared with the total number of GDPs in Wales at the time of the survey) from this group of practitioners was only 39\%. It was disappointing that the response from this group was poor, as the questionnaire was accompanied by a personalised letter from a respected general dental practitioner. The more specialist and varied nature of dental treatment provided by the hospital dental service may have accounted for the higher response rate (44\%) from this group. It was reassuring that a good response to the questionnaire was received from the CDS practitioners (72\%) as this group may be managing more paediatric and adult patients with cardiac problems as a primary and secondary care provider by fulfilling the 'safety net' role of the community dental service. Differences between the three dental service areas are apparent in certain areas of knowledge and will be highlighted throughout the discussion.

\section{Knowledge as to which cardiac conditions require antibiotic prophylaxis for paediatric and adult patients}

Appropriate risk assessment is of paramount importance prior to any procedure for a child or adult who has cardiac risk factors in the prevention of infective endicarditis. Both the type of dental treatment to be provided and the nature of the cardiac defect contribute to the determination of risk.

The guidelines on requirement for antibiotic prophylaxis considered in this paper reflect those current $t^{4,17}$ at the time of the distribution of the questionnaire in 2004-5 and these have remained unchanged with subsequent adult British national formulary publications. Other publications however, such as the Oxford handbook of dental patient care ${ }^{18}$ recommend guidance from the British Cardiac Society and the Royal College of Physicians Clinical Effectiveness and Evaluation Unit ${ }^{10}$ for antibiotic prophylaxis for patients at risk of infective endocarditis. Although the guidelines for the prevention of endocarditis have recently been republished ${ }^{11}$ by the Working Party of the British Society for Antimicrobial Chemotherapy (BSAC), they have not been adopted by the BNF $522006 .{ }^{17}$

The responses to the questionnaire showed most dentists were aware that unrepaired congenital cardiac lesions and valve replacements required antibiotic cover. Poorer knowledge was evident in respect of the change in requirements for $\mathrm{ABC}$ in those paediatric patients who have undergone corrective cardiac surgery. Similarly, dentists were not well informed about the need to provide $A B C$ for patients with a central venous catheter. In general, knowledge of disorders of conduction such as long QT syndrome and Wolff-Parkinson-White syndrome was limited in the GDP and CDS dentists.

\section{Knowledge of which dental procedures require antibiotic} prophylaxis in patients at risk from infective endocarditis Overall, respondents' knowledge of dental risk factors differed significantly by place of work; over half of the dentists responded correctly in all occupation groups, apart from the GDPs. One question asked whether antibiotic prophylaxis was necessary for at-risk patients who required placement of orthodontic bands/brackets. Since current recommendations ${ }^{19}$ advise that orthodontic bands require $A B C$, whilst placement of brackets does not, this question may have caused confusion. Paediatric patients at risk from endocarditis should not have deciduous pulpotomy procedures as they are clinically unjustifiable. ${ }^{19}$ In adults undergoing permanent pulpectomy or root canal therapy, antibiotic prophylaxis is good practice for the 
Table 3 Responses to 04: Which of the following procedures/incidents would require antibiotic prophylaxis for patients at risk of endocarditis?

\begin{tabular}{|c|c|c|c|c|c|c|c|c|c|c|c|c|c|c|c|c|}
\hline \multirow[b]{2}{*}{ Patients with: } & \multicolumn{4}{|c|}{ GDP numbers (\%) } & \multicolumn{4}{|c|}{ CDS numbers (\%) } & \multicolumn{4}{|c|}{ HDS numbers (\%) } & \multicolumn{4}{|c|}{ Other numbers (\%) } \\
\hline & Correct & Incorrect & $\begin{array}{l}\text { Don't } \\
\text { do }\end{array}$ & $\begin{array}{l}\text { Don't } \\
\text { know }\end{array}$ & Correct & Incorrect & $\begin{array}{l}\text { Don't } \\
\text { do }\end{array}$ & $\begin{array}{l}\text { Don't } \\
\text { know }\end{array}$ & Correct & Incorrect & $\begin{array}{l}\text { Don't } \\
\text { do }\end{array}$ & $\begin{array}{l}\text { Don't } \\
\text { know }\end{array}$ & Correct & Incorrect & $\begin{array}{l}\text { Don't } \\
\text { do }\end{array}$ & $\begin{array}{l}\text { Don't } \\
\text { know }\end{array}$ \\
\hline $\begin{array}{l}\text { Exfoliation of } \\
\text { deciduous teeth }\end{array}$ & $\begin{array}{l}321 \\
(83)\end{array}$ & $\begin{array}{l}50 \\
(13)\end{array}$ & $\begin{array}{l}8 \\
(2)\end{array}$ & $\begin{array}{l}7 \\
(2)\end{array}$ & \begin{tabular}{|l|}
79 \\
$(92)$
\end{tabular} & $\begin{array}{l}5 \\
(6)\end{array}$ & 0 & $\begin{array}{l}2 \\
(2)\end{array}$ & \begin{tabular}{|l}
29 \\
$(88)$
\end{tabular} & 0 & $\begin{array}{l}3 \\
(9)\end{array}$ & $\begin{array}{l}1 \\
\text { (3) }\end{array}$ & $\begin{array}{l}17 \\
(74)\end{array}$ & $\begin{array}{l}5 \\
(22)\end{array}$ & $\begin{array}{l}1 \\
(4)\end{array}$ & 0 \\
\hline $\begin{array}{l}\text { Placement of } \\
\text { orthodontic } \\
\text { bands/brackets }\end{array}$ & $\begin{array}{l}60 \\
(15)\end{array}$ & $\begin{array}{l}190 \\
(50)\end{array}$ & $\begin{array}{l}119 \\
(31)\end{array}$ & $\begin{array}{l}17 \\
(4)\end{array}$ & \begin{tabular}{|l}
21 \\
$(24)$
\end{tabular} & $\begin{array}{l}36 \\
(42)\end{array}$ & \begin{tabular}{|l|}
24 \\
$(28)$
\end{tabular} & \begin{tabular}{|l}
5 \\
$(6)$
\end{tabular} & \begin{tabular}{|l}
12 \\
$(36)$
\end{tabular} & $\begin{array}{l}17 \\
(51)\end{array}$ & $\begin{array}{l}3 \\
(9)\end{array}$ & $\begin{array}{l}1 \\
(3)\end{array}$ & $\begin{array}{l}11 \\
(48)\end{array}$ & \begin{tabular}{|l}
6 \\
$(26)$
\end{tabular} & \begin{tabular}{|l}
5 \\
$(22)$
\end{tabular} & $\begin{array}{l}1 \\
(4)\end{array}$ \\
\hline $\begin{array}{l}\text { Orthodontic } \\
\text { tooth separation }\end{array}$ & $\begin{array}{l}29 \\
(7)\end{array}$ & $\begin{array}{l}203 \\
(53)\end{array}$ & $\begin{array}{l}129 \\
(33)\end{array}$ & $\begin{array}{l}25 \\
(6)\end{array}$ & $\begin{array}{l}19 \\
(22)\end{array}$ & \begin{tabular}{|l}
30 \\
$(35)$
\end{tabular} & \begin{tabular}{|l}
31 \\
$(36)$
\end{tabular} & $\begin{array}{l}6 \\
(7)\end{array}$ & \begin{tabular}{|l}
8 \\
$(24)$
\end{tabular} & $\begin{array}{l}17 \\
(51)\end{array}$ & $\begin{array}{l}6 \\
(18)\end{array}$ & $\begin{array}{l}2 \\
(6)\end{array}$ & \begin{tabular}{|l}
12 \\
$(52)$
\end{tabular} & $\begin{array}{l}3 \\
(13)\end{array}$ & $\begin{array}{l}7 \\
(30)\end{array}$ & $\begin{array}{l}1 \\
(4)\end{array}$ \\
\hline $\begin{array}{l}\text { Pulpotomy } \\
\text { (deciduous) }\end{array}$ & $\begin{array}{l}160 \\
(41)\end{array}$ & $\begin{array}{l}181 \\
(47)\end{array}$ & $\begin{array}{l}10 \\
(3)\end{array}$ & $\begin{array}{l}35 \\
(9)\end{array}$ & $\begin{array}{l}35 \\
(41)\end{array}$ & \begin{tabular}{|l}
33 \\
$(39)$
\end{tabular} & \begin{tabular}{|l}
13 \\
$(15)$
\end{tabular} & $\begin{array}{l}5 \\
(6)\end{array}$ & $\begin{array}{l}5 \\
(15)\end{array}$ & \begin{tabular}{|l}
18 \\
$(55)$
\end{tabular} & \begin{tabular}{|l}
8 \\
$(24)$
\end{tabular} & $\begin{array}{l}2 \\
(6)\end{array}$ & \begin{tabular}{|l}
6 \\
$(26)$
\end{tabular} & \begin{tabular}{|l}
12 \\
$(52)$
\end{tabular} & $\begin{array}{l}2 \\
(9)\end{array}$ & $\begin{array}{l}3 \\
(9)\end{array}$ \\
\hline $\begin{array}{l}\text { Pulpectomy } \\
\text { (permanent) }\end{array}$ & $\begin{array}{l}194 \\
(50)\end{array}$ & $\begin{array}{l}159 \\
(41)\end{array}$ & $\begin{array}{l}9 \\
(2)\end{array}$ & $\begin{array}{l}24 \\
(6)\end{array}$ & \begin{tabular}{|l}
50 \\
$(58)$
\end{tabular} & \begin{tabular}{|l}
26 \\
$(30)$
\end{tabular} & \begin{tabular}{|l}
4 \\
$(5)$
\end{tabular} & $\begin{array}{l}6 \\
(7)\end{array}$ & \begin{tabular}{|l}
12 \\
$(36)$
\end{tabular} & \begin{tabular}{|l}
13 \\
$(39)$
\end{tabular} & \begin{tabular}{|l}
6 \\
$(18)$
\end{tabular} & $\begin{array}{l}2 \\
(6)\end{array}$ & $\begin{array}{l}9 \\
(39)\end{array}$ & \begin{tabular}{|l}
5 \\
$(22)$
\end{tabular} & $\begin{array}{l}4 \\
(17)\end{array}$ & \begin{tabular}{|l}
5 \\
$(22)$
\end{tabular} \\
\hline $\begin{array}{l}\text { Placement of } \\
\text { rubber dam }\end{array}$ & $\begin{array}{l}243 \\
(63)\end{array}$ & \begin{tabular}{|l}
97 \\
$(25)$
\end{tabular} & $\begin{array}{l}14 \\
(4)\end{array}$ & $\begin{array}{l}32 \\
(8)\end{array}$ & $\begin{array}{l}43 \\
(50)\end{array}$ & $\begin{array}{l}27 \\
(31)\end{array}$ & $\begin{array}{l}6 \\
(7)\end{array}$ & $\begin{array}{l}10 \\
(12)\end{array}$ & \begin{tabular}{|l}
16 \\
$(49)$
\end{tabular} & \begin{tabular}{|l}
10 \\
$(30)$
\end{tabular} & $\begin{array}{l}5 \\
(15)\end{array}$ & $\begin{array}{l}2 \\
(6)\end{array}$ & \begin{tabular}{|l}
8 \\
$(35)$
\end{tabular} & \begin{tabular}{|l|}
10 \\
$(43)$
\end{tabular} & $\begin{array}{l}3 \\
(13)\end{array}$ & $\begin{array}{l}2 \\
(9)\end{array}$ \\
\hline $\begin{array}{l}\text { RCT where } \\
\text { instruments not } \\
\text { passed through } \\
\text { the root apex }\end{array}$ & $\begin{array}{l}248 \\
(64)\end{array}$ & \begin{tabular}{|l|}
123 \\
$(32)$
\end{tabular} & $\begin{array}{l}1 \\
(0.3)\end{array}$ & $\begin{array}{l}14 \\
(4)\end{array}$ & \begin{tabular}{|l}
61 \\
$(71)$
\end{tabular} & $\begin{array}{l}14 \\
(16)\end{array}$ & $\begin{array}{l}3 \\
(4)\end{array}$ & \begin{tabular}{|l}
8 \\
$(9)$
\end{tabular} & \begin{tabular}{|l|}
23 \\
$(70)$
\end{tabular} & $\begin{array}{l}3 \\
(9)\end{array}$ & \begin{tabular}{|l}
4 \\
$(12)$
\end{tabular} & \begin{tabular}{|l}
3 \\
$(9)$
\end{tabular} & $\begin{array}{l}15 \\
(65)\end{array}$ & \begin{tabular}{|l}
5 \\
$(22)$
\end{tabular} & $\begin{array}{l}2 \\
(2)\end{array}$ & $\begin{array}{l}1 \\
(4)\end{array}$ \\
\hline $\begin{array}{l}\text { Reimplantation } \\
\text { of an avulsed } \\
\text { tooth }\end{array}$ & $\begin{array}{l}335 \\
(87)\end{array}$ & \begin{tabular}{|l|}
13 \\
$(3)$
\end{tabular} & $\begin{array}{l}10 \\
(3)\end{array}$ & $\begin{array}{l}28 \\
(7)\end{array}$ & \begin{tabular}{|l|}
76 \\
$(88)$
\end{tabular} & - & $\begin{array}{l}3 \\
(4)\end{array}$ & \begin{tabular}{|l|}
7 \\
(8)
\end{tabular} & \begin{tabular}{|l|}
31 \\
$(94)$
\end{tabular} & - & $\begin{array}{l}1 \\
(3)\end{array}$ & $\begin{array}{l}1 \\
(3)\end{array}$ & \begin{tabular}{|l|}
23 \\
$(100)$
\end{tabular} & 0 & 0 & 0 \\
\hline
\end{tabular}

Table 4 Mean percentage of questions answered correctly by respondents with $95 \%$ confidence intervals shown in brackets

\begin{tabular}{l|l|l|l|l|l}
\hline $\begin{array}{l}\text { Questions } \\
\text { (number) }\end{array}$ & GDP & CDS & HDS & Other & $p$ \\
\hline $\begin{array}{l}\text { All questions } \\
(26)\end{array}$ & $\begin{array}{l}53.4 \\
(52.1,54.6)\end{array}$ & $\begin{array}{l}61.3 \\
(58.7,63.9)\end{array}$ & $\begin{array}{l}64.8 \\
(60.5,69.2)\end{array}$ & $\begin{array}{l}59.7 \\
(52.3,67.0)\end{array}$ & $<0.001$ \\
\hline $\begin{array}{l}\text { Question 2 } \\
(11)\end{array}$ & $\begin{array}{l}46.3 \\
(44.2,48.4)\end{array}$ & $\begin{array}{l}57.2 \\
(52.7,61.7)\end{array}$ & $\begin{array}{l}65.0 \\
(58.3,71.7)\end{array}$ & $\begin{array}{l}54.2 \\
(42.0,66.3)\end{array}$ & $<0.001$ \\
\hline $\begin{array}{l}\text { Question 3 } \\
(6)\end{array}$ & $\begin{array}{l}62.3 \\
(60.7,63.9)\end{array}$ & $\begin{array}{l}66.9 \\
(63.7,69.9)\end{array}$ & $\begin{array}{l}67.2 \\
(60.8,73.5)\end{array}$ & $\begin{array}{l}68.1 \\
(62.8,73.4)\end{array}$ & 0.02 \\
\hline $\begin{array}{l}\text { Question 4 } \\
(8)\end{array}$ & $\begin{array}{l}46.6 \\
(45.3,47.9)\end{array}$ & $\begin{array}{l}52.26 \\
(49.7,55.5)\end{array}$ & $\begin{array}{l}52.7 \\
(48.0,57.3)\end{array}$ & $\begin{array}{l}52.7 \\
(45.8,59.6)\end{array}$ & $<0.001$
\end{tabular}

first stage of root canal preparation when the working distance is estimated and when there is more chance of an instrument penetrating beyond the root apex. ${ }^{20}$

According to the guidelines current when the survey was conducted, ie the Endocarditis Working Party of the British Society for Antimicrobial Chemotherapy guidelines, ${ }^{4,17}$ the only procedures requiring antibiotic prophylaxis in susceptible patients are extractions, scaling and periodontal surgery. Other publications, however, indicated an underestimate of the procedures which may cause a bacteraemia, ${ }^{5,10}$ and cause considerable confusion. Furthermore, for example, orthodontic procedures such as placement of bands, tooth separation and exposure of canines were stated to require antibiotic prophylaxis. ${ }^{19,21}$ The nebulous term 'procedures causing gingival bleeding' was frequently used in the past as a benchmark for the provision of antibiotic cover, however there was no relationship found between bleeding and the presence of bacteraemia ${ }^{22}$ and the advice was to treat the statement with caution.

Clear improved guidelines for dentists have been long awaited. The revised guidelines for the prevention of endocarditis by BSAC $^{11}$ suggest that all dental procedures in children and adults involving dento-gingival manipulation will require antibiotic prophylaxis in three limited at-risk groups: previous history of infective endocarditis, cardiac valve replacement (mechanical or biological prosthetic valves) and surgically constructed systemic or pulmonary shunts or conduits. The revised guideline, ${ }^{11}$ if adopted, would simplify and clarify the need for antibiotic prophylaxis for dental procedures and may improve compliance.

Knowledge of which dental equipment should not be used for patients with a pacemaker or an implantable cardiac defibrillator The use of cardiac pacemakers and implantable cardiac defibrillators is increasing. ${ }^{3}$ At present, it appears that the majority of dentists would not use an ultrasonic scaler to carry out a scaling in the management of periodontal disease in patients fitted with a pacemaker or an implantable cardiac defibrillator (ICD). This advice would presumably be followed by any dental care professional working within the dental team under the guidance of the dentist.

A variety of ultrasonic scalers are in current use. Trenter and Walmsley ${ }^{23}$ reviewed the risks associated with ultrasonic dental scalers for patients with pacemakers, concluding that piezoelectric scalers did not affect pacemakers. Magnetostrictive ultrasonic scalers should not be used in patients with pacemakers ${ }^{24}$ because of the electromagnetic field produced by the handpiece and cable that occurs within $37.5 \mathrm{~cm}$ of the 
pacemaker. The original cardiac pacemaker models were unipolar and poorly insulated, therefore more liable to being affected by electrical devices than the modern bipolar titanium insulated ones. Modern piezoelectric ultrasonic scalers and sonic scalers are unlikely to have a significant effect, with minimal risk of dysfunction on newer cardiac pacemakers; however, activity-rate-responsive devices may exhibit faster pacing rates. ${ }^{25}$

Scully and Cawson ${ }^{26}$ advise "the only safe procedure under such circumstances is to avoid the use of all such equipment whenever a patient with a pacemaker is being treated as it is difficult to assess the level of risk in any individual patient.' They advise treating a patient in a supine position with electrical equipment placed $30 \mathrm{~cm}$ away and to avoid rapid repetitive switching of electrical instruments. Current guidance in the British national formulary ${ }^{17} 2006$ states that some ultrasonic scalers can interfere with the normal functioning of pacemakers (including shielded pacemakers) and should not be used. The manufacturer's literature should be consulted whenever possible. ${ }^{17}$

The need for a review of advice on use of ultrasonic scalers has been the subject of series of letters in the British Dental Journal. ${ }^{27-29}$ The need for individual assessment of the pacemaker type and specific advice on the manufacturer's data manual were felt to be important in order that this effective method of periodontal treatment could be performed without adverse consequences. Clearly, more in vivo research is needed in this area for the benefit of patients and dental healthcare workers with pacemakers.

Apart from ultrasonic dental scalers, a third of responding dentists would not use electrocautery devices in patients with pacemakers or implantable cardiac defibrillators, whilst a minority cited concerns over other devices such as apex locators, electric pulp testers, Diagnodent, orthopantomographs, lasers, LED light curing machines, TENS machines, sonic toothbrushes, belt driven chairs, electric motors and piezoelectric devices.

Most dental authors agree that surgical diathermy can affect the function of pacemakers or implantable cardiac defibrillators..$^{24,26,30}$ Ultrasonic baths may also have an effect. ${ }^{23,24}$ Improvements in the titanium shielding and use of increased filtering circuits in pacemakers have meant that certain dental devices can be used safely in patients with pacemakers. ${ }^{24}$ The use of electric pulp testers, radiography units, composite curing lights, amalgamators, dental chairs, lights and handpieces would not appear to cause interference with pacemakers. However, Miller et al. ${ }^{24}$ advised that electrocautery units, ultrasonic baths and magnetorestrictive ultrasonic scalers should be avoided. The importance of understanding how pacemakers and implantable cardioverter defibrillators work and the possible effects of electromagnetic interference was highlighted in a review by Allen in 2006. ${ }^{31}$ Further clinical research is required in dentistry to ensure that commonly used electromagnetic dental equipment is safe. The Medicines and Healthcare Products Regulatory Agency in 2006 published guidelines for the periooperative management of patients with implantable pacemakers or implantable cardioverter defibrillators. ${ }^{32}$

The use of electronic endodontic devices to aid in diagnosis and facilitate root canal therapy is common. The in vitro effect of electronic apex locators on cardiac pacemaker function was explored by Garofalo et al. ${ }^{33}$ who concluded that laboratory evidence suggested these devices could be used safely in patients with pacemakers. The lack of clinical data and difficulty in setting up human trials means that manufacturers continue to issue warnings in data sheets against the use of electric pulp testers, ${ }^{34}$ electronic apex locators ${ }^{35,36}$ and motorised handpieces for endodontic treatment with additional electronic canal measuring facilities ${ }^{37}$ in patients with pacemakers, in order to obtain FDA approval for their use. The manufacturer's data sheets ${ }^{38}$ for Piezon Master 400 advise that ultrasonic oscillations may prevent cardiac pacemakers from functioning properly and their use in such patients is not recommended.

\section{Strategy to be adopted when advice was required on antibiotic prophylaxis}

In the situation where the dentist is unsure about the need to provide antibiotic prophylaxis, most respondents stated that they would approach either the patient's general medical practitioner or cardiac consultant. Though this improved communication between dental and medical practitioners is to be applauded, it should be noted that several respondents commented that general medical practitioners and hospital consultants often did not reply to their communications. Others felt that doctors were more likely to recommend antibiotic prophylaxis in order to cover medico-legal eventualities rather than on a specific case basis. This could be the reason that increasing numbers of medically compromised patients who could be treated in the general dental service are being referred to dental hospitals and oral and maxillofacial departments. ${ }^{39}$

Patients with cardiac disease receiving treatment in an inpatient environment have access to cardiology services for opinions as to which cardiac anomalies or conditions require antibiotic prophylaxis in the prevention of infective endocarditis, however general dental practitioners (GDPs) and CDS practitioners do not have the immediate access to multidisciplinary interaction, advice and support available to hospital dentists. The contact details of regional and district medicines information services are available on the inside cover of the $B N F^{17}$ and are a valuable resource for information on drug regimens and potential interactions.

\section{Continuing educational needs and preferred method of learning}

Although GDPs and CDS practitioners perform the majority of dental procedures on cardiac patients in the community, there has been little emphasis on the continuing educational needs of these primary care providers. Knowledge of cardiac risk factors would be gained as undergraduates, during training posts or through in-service training; however, advances in surgical management of cardiac conditions and risk factors may not have formed part of the continuing professional development of all dental practitioners. There appears to be confusion regarding the management of paediatric and adult patients with cardiac risk factors and this is compounded by lack of knowledge and standardised guidelines. It is, therefore, perhaps unsurprising that answers to this questionnaire were so variable. Reassuringly, but disappointingly, similar studies in Australia, ${ }^{40}$ England $^{41}$ and Spain $^{42}$ have shown comparable results. 
There is evidently a need for regular dissemination of information about cardiac risk factors. It would be useful for relevant conditions to be included in the $B N F^{17}$ to which the majority of dentists and doctors refer. Many community and hospital trusts provide guidelines on which cardiac conditions and dental procedures require antibiotic prophylaxis, however these may not be disseminated widely to primary care dental practitioners.

Since continuing professional development is an obligatory part of registration with the General Dental Council, ${ }^{43}$ it is unsurprising that the majority of dentists (especially GDPs and CDS dentists) were eager to attend a formal postgraduate course. It may be surmised that most dentists favour the idea of a laminated flow diagram for their surgeries because they can have these readily available, often being placed on the surgery wall. Surprisingly, email and the introduction of a website were much less popular, despite the fact that, in these formats, update is more readily facilitated. CD-ROM was also less requested in this survey and may indicate to providers of educational material that another educational format would be preferred.

\section{CONCLUSION}

Knowledge of Welsh dentists varied according to whether they worked within the general dental services, community dental service or hospital dental services, as to which cardiac conditions or procedures were risk factors for paediatric and adult patients. There is confusion as to which patient groups and cardiac conditions require prophylaxis and for which particular dental procedures. The study identified potential for under- and over-prescription of antibiotic prophylaxis under the current guidance. Clearly, there is need for clarity in which congenital, acquired and repaired cardiac conditions require antibiotic prophylaxis for the prevention of infective endocarditis. The role of general medical practitioners is also important and guidelines should be readily accessible by dentists and doctors alike. It is also incumbent upon cardiologists to ensure that dentists are well informed about their patients' medical treatment, either via post or a medical alert card. In order to avoid confusion between the medical community and patient/carer groups, Reeves ${ }^{44}$ suggested that the Department of Health should take a lead on this issue.

While it is beyond the scope of this paper to consider the rationale for changes in guidance concerning antibiotic prophylaxis, this study clearly shows that practitioners are confused by its practical application. This may have ramifications in respect of over- and under-prescription of antibiotic prophylaxis for paediatric and adult patients with cardiac conditions, as well as the dental procedures undertaken for such patients.

Revised guidance has been published since the completion of the study (Guidelines for the prevention of endocarditis: report of the Working Party of the British Society for Antimicrobial Chemotherapy ${ }^{11}$ and it is anticipated that the Department of Health will refer to the National Institute for Clinical Effectiveness (NICE) ${ }^{45}$ before changes to current guidance are disseminated in future editions of the British national formulary. ${ }^{17}$

Knowledge of the safe use of electromagnetic dental devices in patients with pacemakers or implantable cardioverter defibrillators is poor. Postgraduate education in advances in cardiology practice and appropriate prescribing for patients at risk of infective endocarditis is necessary and desirable to the majority of dentists surveyed. The study found that the majority of dentists preferred to receive updates in antibiotic guidance by flow diagrams that can be laminated for their surgeries.

The authors would like to thank the School of Postgraduate Medical and Dental Education for Wales for its support, Dr Zoe Roberts of the Department of Statistics and Epidemiology, Cardiff University for her statistical advice and Professor M. L. Lewis for his comments.

1. Ferrieri P, Gewitz M H, Gerber M A et al. Unique features of infective endocarditis in childhood. Circulation 2002; 105: 2115-2138.

2. Al-Karaawi Z M, Lucas V S, Gelbier M, Roberts G J. Dental procedures in children with severe congenital heart disease: a theoretical analysis of prophylaxis and non-prophylaxis procedures. Heart 2001; 85: 66-68.

3. Report of the British Cardiac Society Working Party. Grown up congenital heart (GUCH) disease: current needs and provision of service for adolescents and adults with congenital heart disease in the UK. Heart 2002; 88 (Suppl): i1-i14.

4. Simmons N. Recommendations for endocarditis prophylaxis. J Antimicrob Chemother 1993; 31: 437-438. In British national formulary. London: BMJ Publishing Group Ltd and the Royal Pharmaceutical Society of Great Britain, 2006.

5. Dajani A S, Taubert K A, Wilson W et al. Prevention of bacterial endocarditis. Recommendations by the American Heart Association. J Am Dent Assoc 1997; 128: $1142-1151$.

6. Dajani A S, Taubert K A, Wilson W et al. Prevention of bacterial endocarditis. Recommendations by the American Heart Association. J Am Med Assoc 1997; 277: 1794-1801.

7. Lockhart P B, Brennan M T, Fox P C, Norton H J, Jernigan D B, Strausbaugh L J. Decision-making on the use of antimicrobial prophylaxis for dental procedures: a survey of infectious disease consultants and review. Clin Infect Dis 2002; 34: 1621-1626.

8. Cheuk D, Wong $S$, Choi Y, Chau A, Cheung Y. Parents' understanding of their child's congenital heart disease. Heart 2004; 90: 435-439.

9. Lowry R J, Maunder P, Steele J G et al. Hearts and mouths: perceptions of oral hygiene by at-risk heart surgery patients. Br Dent J 2005; 199: 449-451.

10. Roberts G J, Ramsdale D, Lucas V S. Dental aspects of endocarditis prophylaxis: new recommendations from a Working Group of the British Cardiac Society Clinical Practice Committee and Royal College of Physicians Clinical Effectiveness and Evaluation Unit. 19 April 2004. http://www.rcseng.ac.uk/fds/docs/ie_recs.pdf

11. Gould F K, Elliott T S J, Foweraker J et al. Guidelines for the prevention of endocarditis: report of the Working Party of the British Society for Antimicrobial Chemotherapy. J Antimicrob Chemother 2006; 57: 1035-1042.

12. The Task Force on Infective Endocarditis of the European Society of Cardiology. Guidelines on prevention, diagnosis and treatment of Infective Endocarditis. Eur Heart J 2004; 25: 267-276.

13. Oliver R, Roberts G J, Hooper L. Penicillins for the prophylaxis of bacterial endocarditis in dentistry. Cochrane Database Syst Rev 2004: CD003813.

14. Ahmed M F, Elseed A I. The medical management and dental implications of Long OT syndrome. Dent Update 2005: 32: 472-474

15. Michaloudis D, Fraidakis O, Petrou A, Gigourtsi C, Parthenakis F. Anaesthesia and the QT interval. Effects of isoflurane and halothane in unpremedicated children. Anaesthesia 1998: 53: 435-439.

16. SPSS. SPSS Inc. 233 S.Wacker Drive, $11^{\text {th }}$ Floor, Illinois, Chigago, 60606, USA.

17. British national formulary 51 and 52. London: BMJ Publishing Group Ltd and RPS Publishing, 2006

18. Scully C, Kalantzis A. Oxford handbook of dental patient care. Oxford: Oxford University Press, 2005

19. Welbury R, Duggal M, Hosey M T. Paediatric dentistry. 3rd ed. Oxford: Oxford University Press, 2005.

20. Ricucci D. Apical limit of root canal instrumentation and obturation, part 1. Literature review. Int Endod J 1998; 31: 384-393.

21. Khurana M, Martin M. Orthodontics and infective endocarditis. Br J Orthod 1999; 26: 295-298.

22. Roberts G. Dentists are innocent! "Everyday" bacteremia is the real culprit: a review and assessment of the evidence that dental surgical procedures are principal cause of bacterial endocarditis in children. Pediatr Cardiol 1999; 20: $317-325$

23. Trenter S, Walmsley A. Ultrasonic dental scaler: associated hazards. J Clin Periodontol 2003; 30: 95-101.

24. Miller $\mathrm{C}$, Leonelli $\mathrm{F}$, Latham E. Selective interference with pacemaker activity by electrical dental devices. Oral Surg Oral Med Oral Pathol 1998; 85: 33-36.

25. Rees T. Periodontal management of patients with cardiovascular diseases. J Periodontol 2002; 73: 954-968.

26. Scully C, Cawson R A. Medical problems in dentistry. 5th ed. London: Elsevier Ltd, 2005.

27. Balfry G. Pacemakers and ultrasonic scalers. Br Dent J 2005; 199: 625 .

28. Firth R. Practicing with pacemakers. Br Dent J 2006; 200: 124.

29. Alexander M. Scalers: review advice. BrDent J 2006; 200: 183.

30. Luker J. The pacemaker patient in the dental surgery. J Dent 1982; 10:326-332.

31. Allen M. Pacemakers and implantable cardioverter defibrillators. Anaesthesia $2006 ; 61: 883-890$ 


\section{RESEARCH}

32. Medicines and Healthcare Products Regulatory Agency. Guidelines for the periooperative management of patients with implantable pacemakers or implantable cardioverter defibrillators, where the use of surgical diathermy/electrocautery is anticipated. London: Medicines and Healthcare Products Regulatory Agency, 2006.

33. Garofalo R, Ede E, Dorn S, Kuttler S. Effect of electronic apex locators on cardiac pacemaker function. J Endod 2002; 28: 831-833.

34. Analytic Technology. Vitality scanner instruction guidelines. Analytic Technology, WA, USA

35. Analytic. Apex finder instruction guidelines. Analytic, Sybron Dental Specialties, USA.

36. J. Morita MFG Corp. Root ZX operation instructions. J. Morita MFG Corp, Europe.

37. J. Morita MFG Corp. Tri Auto ZX operation instructions. J. Morita MFG Corp, Europe.

38. EMS Piezon Master 400 operating instructions.
39. Absi E, Satterthwaite J, Shepherd J, Thomas D. The appropriateness of referral of medically compromised dental patients to hospital. Br J Oral Maxillofac Surg 1997; 35: 133-136.

40. Jaunay T, Sambrook P, Goss A. Antibiotic prescribing practices by South Australian general dental practitioners. Aust Dent J 2000; 45: 179-186.

41. Palmer N, Pealing R, Ireland R, Martin M. A study of prophylactic antibiotic prescribing in National Health Service general dental practice in England. Br Dent J 2000; 189: 43-46.

42. Tomas I, Diz P, Limeres J et al. Chemoprophylaxis of bacterial endocarditis recommended by general dental practitioners in Spain. Med Oral 2004; 9: 56-62.

43. General Dental Council. Standards for dental professionals. London: General Dental Council, 2005

44. Reeves D. Another set of quidelines? [Editorial] J Antimicrob Chemother 2006; 57: 1023.

45. Confusion over prophylaxis. BDA News 2006 September 9: 19.

\section{Appendix 1 Questionnaire with correct responses}

\section{Q1 Currently, where is your main place of work?}

General dental practice

Community dental service

Hospital dental service

Specialist dental practice, please specify

\section{Which of the following groups of paediatric patients (under 16 years old) require antibiotic prophylaxis for dental extractions?}

\begin{tabular}{|c|c|c|c|}
\hline Patients with: & Yes & No & Don't know \\
\hline Unrepaired ventricular septal defect & $\checkmark$ & & \\
\hline Repaired ventricular septal defect & & $\checkmark$ & \\
\hline Unrepaired patent ductus arteriosis & $\checkmark$ & & \\
\hline Repaired patent ductus arteriosis & & $\checkmark \quad$ No after $6 / 12$ & \\
\hline Unrepaired atrial septal defect & $\checkmark$ & & \\
\hline Repaired atrial septal defect & $\checkmark$ Patch & $\checkmark \quad$ No patch & \\
\hline Patent foramen ovale (PFO) & $\checkmark$ & & \\
\hline Heart valve replacement & $\checkmark$ & & \\
\hline Central venous catheter & $\checkmark$ & & \\
\hline Wolff-Parkinson-White (WPW) syndrome & & $\checkmark$ & \\
\hline Long OT syndrome (LOTS) & & $\checkmark$ & \\
\hline
\end{tabular}

\section{Q3 Which of the following groups of adult patients require antibiotic prophylaxis for dental extractions?}

\begin{tabular}{|c|c|c|c|}
\hline Patients with: & Yes & No & Don't know \\
\hline Innocent heart murmur (no valve defects, normal echocardiogram) & & $\checkmark$ & \\
\hline Pacemaker or an implantable cardiac defibrillator & & $\checkmark$ & \\
\hline Supraventricular tachycardia and a structurally normal heart & & $\checkmark$ & \\
\hline Vasovagal syncope & & $\checkmark$ & \\
\hline Hypertrophic obstructive cardiomyopathy & $\checkmark$ & & \\
\hline Wolfe-Parkinson-White (WPW) syndrome & & $\checkmark$ & \\
\hline
\end{tabular}


Q4 Which of the following procedures/incidents would require antibiotic prophylaxis for patients at risk of endocarditis?

\begin{tabular}{|l|l|l|l|l}
\hline & Yes & No & Don't know & $\begin{array}{l}\text { Don't normally } \\
\text { do this procedure }\end{array}$ \\
\hline Exfoliation of deciduous teeth & & $\checkmark$ & \\
\hline Placement of orthodontic bands/brackets & $\checkmark \quad$ Bands & $\checkmark \quad$ Brackets & & $\checkmark$ \\
\hline Orthodontic tooth separation & $\checkmark$ & & \\
\hline Pulpotomy (deciduous) & & & \\
\hline Pulpectomy (permanent) & $\begin{array}{l}\checkmark \\
\text { only }\end{array}$ & & \\
\hline Placement visit & & $\checkmark$ & \\
\hline $\begin{array}{l}\text { Root canal treatment where instruments are not passed } \\
\text { through the root apex }\end{array}$ & & $\checkmark$ & & \\
\hline Reimplantation of an avulsed tooth & $\checkmark$ & & \\
\hline
\end{tabular}

05 If a patient was fitted with a pacemaker or an implantable cardiac defibrillator, would you use an ultrasonic scaler to perform a scale and polish?

\begin{tabular}{|l|l|l}
\hline Yes & No & Don't know \\
\hline
\end{tabular}

06 Are you aware of any dental equipment that should not be used in patients fitted with a pacemaker or an implantable cardiac defibrillator?

\begin{tabular}{|l|l|}
\hline Yes & Please specify \\
\hline No & Don't know \\
\hline
\end{tabular}

Q7 If you were unsure of whether a patient required antibiotic prophylaxis, what would you do?

\begin{tabular}{l|l}
\hline & Tick one only \\
\hline Happy to treat in own practice & $\square$ \\
\hline Refer to dental hospital/local oral surgery unit & $\square$ \\
\hline Consult patient's GMP & $\square$ \\
\hline Consult patient's cardiologist & $\square$ \\
\hline Other, please state & \\
\hline
\end{tabular}

Q8 Do you feel you would benefit from a formal postgraduate course to update you on antibiotic prophylaxis and endocarditis risk?

\begin{tabular}{|l|l|l}
\hline Yes & No & Don't Know \\
\hline
\end{tabular}

Q9 We intend to produce a guide to updates in congenital heart disease; how would you prefer to receive this information?

\begin{tabular}{|l|l|l}
\hline Laminated flow diagram $\square$ & CD ROM $\square$ & Via Email $\square$ \\
\hline Website $\square$ & Other $\square$ & Please specify \\
\hline
\end{tabular}

Thank you 